\title{
The North-East Coast Exhibition at Newcastle-upon-Tyne.
}

$\mathrm{T}$ HIS is an exhibition with a purpose ; it is the gallant attempt of a depressed area to help itself. The genesis of the idea was inside the Chamber of Commerce on Newcastle Quayside ; afterwards it was taken up by the Lord Mayor and Corporation ; it has been carried through by the leaders of industry working as citizens in committees under a general council representative of the as. sociated cities. The idea is the quest for business through associated advertisement and salesmanship.

The Exhibition is in a corner of the Town Moor behind the Hancock Natural History Museum and about a mile from the Central Station. It is easily accessible by tram. Turning round for a moment before entering the gates, Armstrong College and its new Mining Department are seen 300 yards away. Just inside the Exhibition turnstiles a kiosk supplies an "Official Guide" (price $3 d$.) with a plan of the main buildings. These include Palaces of Engineering, Industries, and Arts, a Festival Hall for conferences, a Stadium for boy scouts, an Amusements Park, and the sideshows of the evening newspapers. An "Official Catalogue" (price 1s.), bought before leaving and studied at home, will save time on a second visit. This contains the names and portraits of the organisers, a list of exhibits, plans, and full indices. It is a very handy volume, indicative of excellent general organisation. A more bulky "Exhibition Year Supplement" of the Newcastle and Gateshead Chamber of Commerce Journal (price $2 s .6 d$.), is obtainable in the Guildhall on the Quayside. It contains a trade index of industries with illustrated advertisements. It seems valuable for strangers intending to place large orders or inquiring into the industrial environment before choosing sites for new works.

The natural products of the area include not only coal but also whinstone and limestone for roadmaking, freestone for building, grindstones from the millstone grit, lime from both carboniferous and magnesian limestones, magnesia from the latter, fireclay from beneath the coal, brick-clay from nearer the surface, brine from the trias, and ironstone from the oolite. Navigable estuaries admit shipping and encourage shipbuilding, deep river gorges have stimulated the bridge builders, Cleveland iron-stone and Durham coal have made the Middlesboro' iron and steel industry which supplies material for all the engineering works. Tyneside was the birthplace of Stephenson and of the locomotive. More lately the district has been to the front in the production of high tension electric supply in alternators driven by Parsons turbine machinery, and this electric current has been applied to railway traction and through a grid for other industrial purposes.

The greatest engineering triumphs will not fit into exhibitions. The new Tyne Bridge with roadway slung from an arch apparently parabolic is seen when entering Newcastle from the south. The Mauretania and its floating dock may be seen at Southampton. The latest colliery improvements are in the collieries and at work. Locomotives and rolling stock are on the railways. Within the Palace of Engineering these greater objects can only be represented by pictures and models; 30 tons has been the limit, a steam rail coach brought in by the London and North-Eastern Railway Company. A few other exhibits are here named as samples, not as a catalogue.

Sir Howard Grubb, Parsons and Co., show a reflecting telescope of 3 -feet aperture intended for the Royal Observatory, Edinburgh. It is designed in accordance with specifications by Prof. R. A. Sampson, and is to be used chiefly for spectroscopic work. The parabolic mirror and auxiliary hyperbolic mirror combine to make an equivalent focal length of 54 feet. The driving circle is clamped to the polar axis by hydraulic pressure. The driving clock has both its own frictional governor and also a control by impulses received every second from an observatory timekeeper.

Messrs. Reyrolle and Co. have specialised on switch-gear for large electric power stations. With voltages of 33,000 the contacts are made and broken under oil and inside earthed metal-clad cases.

Imperial Chemical Industries explain, by means of a cinema hall, what their associated companies are doing at Billingham. Pictures show how the fertilisers make the grass grow in intensive culture paddocks. Specimens of various products are shown, Billingham carbonate of lime, nitro-chalk and imported nitro-phoska, chlorine for water purification, Portland cement, etc.

The Thermal Syndicate is an example of a new industry made possible by electric supply. Its ' vitreosil' or fused silica finds increasing applications due to its high melting point, low coefficient of expansion, transparency to ultra-violet light, non-conduction of electricity and resistance to acid. The size of worm-tubes for condensation has greatly increased. Also for laboratory use is the Pyrex glass made in Sunderland. There are numerous domestic electrical appliances for heating and cooking. The Electric Lamp Manufacturers' Association is advising on the best methods of industrial lighting.

Among recent developments of driving machinery are the Diesel and half-Diesel engines. A new Doxford engine has no closed ends to its cylinders but two pistons both moving outwards. The great production of metal work has been a stimulus to paint, enamel, and anti-fouling compositions. A coke maker is using $\mathrm{X}$-rays to detect unseen impurities. A toffee-making machine, automatic with endless band, attracts attention. But it is not only the toffee and the toffee-making machine that matter. Behind it stands the maker of the toffeemaking machine, and the possibility of inventing other machines with continuous output at increasing profits for other industries. Unfortunately, unlike a toffee works, a coal-mine exhausts its product; it cannot expand indefinitely, it must finance its sinking funds on other principles. This and other (Continued on p. 27.)

No. 3114, Vor. 124] 
exhibits auxiliary to local industry come from the south. The Cambridge Scientific Instrument Company supplies its pyrometers to brick and tile works.

The natural advantages already described are open to those who wish to start new industries. In chemicals, iron, engineering, and shipbuilding it may be less easy to begin on a small scale than it was a century ago with less powerful competitors. But the district seems a good one for new inventions operating new patents. Coal, gas, and electric current are available as power. There is a network of railways and motor-bus routes. There is superabundant labour already somewhat housed. New ventures will be welcomed by a population reluctant to emigrate although ill-advised in leaving initiative to others. The large-scale models of the Tyne Improvement and Tees Conservancy Commissioners will help in the choice of sites for factories; the L.N.E.R. is also ready to advise. Industries scarcely yet acclimatised include the making of agricultural machinery and motorlorries.

This exhibition goes much further than earlier attempts to restore confidence by talking confidence. The goods are ready. The method of advertisement is being pushed for all it is worth. Word has gone out through the world in English, French, German, and Spanish. There will be conferences of advertisers, of international foundrymen, and notably the Baltic and White Sea Conference. The success of the exhibition is to be judged by orders for ships, bridges, and machinery rather than by gate-money on bank holidays. The method of advertisement may have its limits; it may lead to private profit at the price of public waste. The exhibition and its catalogues are examples of economy in advertisement by cooperation, a stepping-stone towards the transformation of advertisement into a public service. The relation of the co-operative wholesale society to the co-operative stores in the pit-villages tends towards the tied-house principle, eliminating the need for advertisement. Even if the method of advertisement cannot command success, it is doing what it can to deserve it.

So much for the microcosm in which the scientific explorer will find himself if he comes to make the exhibition a starting-point for some survey of the north-east of England. The causes of present distress have been incompletely advertised. It is not only a post-War slump in munitions. For fifty years Tyneside has been content to make high profits and high wages whilst specialising in the production of munitions. Nemesis has come home with a vengeance. There is a heavy load of the disabled to be carried; the education of the blind is the only formal educational exhibit. The unemployed include the less employable and the less versatile. Leadership has been decimated. Unemployment as a name for a scarcity of employers is a view not emphasised by labour leaders. Labour propaganda has looked numbly to the State. During the coal stoppage of 1926 it may have seemed right to say hold on and hope. In retrospect, emigration would have been wiser. Many of the inland coal mines, for example near Bishop Auckland, are worked out, though the deeper mines near the Durham coast are at work. It seems a tragic mistake that emigration has been discouraged by those to whom the miners look for advice. The Lord Mayor's Fund has been a gesture of generosity; it only makes idleness a trifle less intolerable.

Various tempers of mind-religious, philanthropic, political-have already been applied to our problems without yielding complete solutions. Before prescribing panaceas we need the whole truth. It is whispered that in the past it has been far too easy to make money on Tyneside. This view is endorsed by Dr. H. A. Mess in "Industrial Tyneside". Traditional industries have scarcely thought it necessary to bring in scientific advice; even to-day a chemist is felt to be out of place on a board of directors. Some industries requiring high intelligence have left the district ; electric lamps and aniline dyes are examples. So far there is too little response to the offers of the National Institute of Industrial Psychology to help in selecting personnel and arranging work. There is a reluctance to climb down from high prices, high profits, and high wages.

What is to be done if the method of advertisement fails ? The restoration of the general prosperity of our neighbours beyond the North Sea is urgent. A voluntary Interessengemeinschaft between chemical firms, already in the imperial stage of evolution, would be a safeguard against future misuse of nitrates and by-products. Armstrong College, fed by scholarships through the secondary schools, is preparing the next generation of employers. Even if the rest of England hesitates there seems a fair case for asking for a prior and immediate application of the Hadow Report raising the school age by one year in the colliery areas. For the next or prevocational year up to age sixteen the teachers are still to be discovered and trained. A great development of junior technical schools is desirable until every young person has at least one and preferably several ways of earning a living. It is proving very difficult to reconvert townsfolk into agriculturalists. There is a Migration Training Hostel for boys in Walker, and a Domestic Training Hostel for girls in Benton, but what are these among so many?

Emigration is probably urgent and almost without waiting to ask whether the new countries will speak Russian, Spanish, or Dutch. When customers are invited from all nations it seems absurd to limit emigration to the British Empire. The nations emigrating to America have faced a new language and an alien culture. A generation ago the Irish had to leave home: a like fate is before our boys and girls. The best ages for emigrating are said to be sixteen to twenty-three, and the best form of assistance education and training whilst still near home. Some sort of vocational guidance might be offered to every one, followed by technical training according to capacity. The boys and girls in their school caps and badges are seen eagerly examining the exhibits; to them the exhibition is a means of education.
Hugh Richardson.

No. 3114, VoL. 124] 